\title{
A Comparative Study of Self-expression and Catharsis in Theory of Mystical Journey at Mantiq-uț-Ṭar (Conference of the Birds) and Biodanza
}

\author{
Simin Meshkati
}

\begin{abstract}
Spiritual consciousness can come in many forms; it can happen during moments of dance or even in poetic narrations. This article is designed to compare self -expression and spiritual development through Dance and Poetic Mysticism. The question arises, how different theoretical foundation can reach to psychological catharsis. It is supposed that a mystic journey is going to be closed with catharsis. During this journey, the main character (the dancer, the reader or spectacular) will undergoes Discovery and Reversal to reach the catharsis, which means cleansing, purging, or purification. Seymour Feshbach, key proponent of the catharsis theory in communication research, separates three conceptions of catharsis: The Dramatic, the Clinical, and the Experimental models. The thought behind catharsis theory is that feelings formed and create stress if not expressed. Releasing emotions declines the tension in the person so they have less violent and anxiety. The Dramatic and Clinical models are emphasized on change, while differing in cathartic experience, in the degree of cognitive representation caused, and in the interpersonal context.

The purpose of this study is to give a psychological study of mysticism by reviewing The Seven Valleys of spirituality in Conference of the Birds. Attar has described the seven stages of spirituality in this book as the tools of discovery and rehearsal: The Valley of Quest, The Valley of Love, The Valley of Wisdom, The Valley of Detachment, The Valley of Unity, The Valley of Amazement, and The Valley of Annihilation. To free from belongings, to release from the self, these seven valleys is suggested by Attar to be passed. self is one of the biggest obstacles in human life. In the eyes of the mystics, you must "Quest" first. Attar is a mystic who has put "Annihilation" in the last place. Sober die has not a tragic meaning but means of getting free of self and join the real source of nature.

On the other side, Biodanze is also another journey that can interpreted by theory of catharsis. Toro believes that when five categories are entirely developed within the individual, people (the dancer) can experience inner stability and emotional health. He named these categories as Vitality, Sexuality, Creativity, Affection, and Transcendence. Journey in Biodanza is started by vital impetus and happiness to be alive. The dancer will reach to catharsis when he connects to nature and feel part of a greater totality.
\end{abstract}

Keywords - Mystic, Catharsis, Biodanza, Conference of Birds.

Simin Meshkati, M.A. Dramatic Literature, Department of Art and Arcitecture, Tarbiat Modares University, Tehran, Iran

\section{MantiQ-Ut-TAYr(CONFERENCE OF The BIRDS)}

In the poem, the birds of the world gather to choose who is to be their supreme, as they have none. The hoopoe, the wisest of them all, suggests that they should find the mythical Simorgh. Each of birds represents a human vice, which prevents him from attaining awareness and consciousness. The birds have to pass seven valleys in order to reach the Simorgh. In Attar's outstanding allegory for the journey of the soul as it seeks union with the divine, there are seven valleys as follows: [1]

1. Valley of the Quest, where the Wayfarer begins by casting aside all dogma, belief, and unbelief.

2. Valley of Love, where reason is abandoned for the sake of love.

3. Valley of Knowledge, where worldly knowledge becomes useless.

4. Valley of Detachment, where all desires and attachments to the world are given up. Here, what is assumed to be "reality" vanishes.

5. Valley of Unity, where the Wayfarer realizes that everything is connected and that the Beloved is beyond everything, including harmony, multiplicity, and eternity.

6. Valley of Wonderment, where, entranced by the beauty of the Beloved, the Wayfarer becomes perplexed and, steeped in awe, finds that he or she has never known or understood anything.

7. Valley of Poverty and Annihilation, where the self disappears into the universe and the Wayfarer becomes timeless, existing in both the past and the future.[2]

When the birds hear the portrayal of these valleys despite their anxieties, they commence the prodigious journey. On the way, many decease of dryness, illness, panic, and vehemence. Finally, only thirty birds make it to the Simorgh. In the end, the birds apprehend that they themselves are the Simorgh( Simorgh in Persian means thirty birds). According to Attar, the perfect servant of God must go through the steps in order to leave illusory and sensible, which is the stage of lust and covetous desires; also has to be over with the intellectual 
concept which is a source of pride; while he must forbear the nonexistent which is the source of fraud in order to achieve the unity and the perfection and the vicegerency of God[3]. Meanwhile according to illuminative philosophy, a human is a microcosm and a God's manifestation and if he removes physical appearances and effects, he will be the God's vicegerent and the God himself[ 4].

\section{EXPRESSING SELF IN THE MYSTIC JOURNEY BY BIRDS}

The term self is used in many different ways. I currently use self, soul, and psyche interchangeably in order to refer to the whole being of an individual human. Nafs (نَفْس) is also an Arabic word, literally connotes self. The word is signifying that although humanity is united in having the positive qualities of self, they are individually responsible for exercising the interventions of the free will that it is responsible for them. My use of self is thus in reference to an individual's totality of body, mind, and spirit. I use the capitalized Self to denote a Supreme Uniqueness that transcends single human existence. This Supreme Identity is an entire and divine Self that is considered by mystics beyond all visible things. In this way, Self refers to the whole of the One and All just as self does to the whole of the individual human. At the Conference of the Birds" the capitalized Self is thus practically synonymous with God.To Attar, the seven valleys are inner, mystical, or psycho-spiritual dimension of self to join the Self. The Path of valleys is a matrix of transformation, refining, purifying, elevating all relationships.Attar repeatedly warns us about our selves, our Nafs . In Sufi tradition, self stands between our true and the God. Once it is destroyed, the catharsis may come true by uniting with the Divine and hence recover our true self. In this school, to die means to let go of self, and when that happens all obstacle and veils will disappear. Even though all paths eventually lead to the united Self, the annihilation of the self shortens the path to the Ultimate Source and identity.

The Conference of the Birds is a symbolic poem about

human struggle, both corporal and spiritual. These parables guide and instruct human to animate the deeper meanings of what consider as reality.

The end of this journey is not self-scarifying, but it is the Catharsis. Catharsis is the purification and purgation of emotions that results in renewal and restoration. The theory of catharsis has a disarming affinity with the expressional theory, since it emphasizes emotion, asserts a change in emotion as result of aesthetic operations, and concludes on a note of freedom in relation to the emotion [5]. It is a metaphor originally used by Aristotle in the Poetics, comparing the effects of tragedy on the mind of a spectator to the effect of a cathartic on the body. However, how the catharsis is possible trough journey of birds? The mystic journey of Birds is hierarchical. The wayfarer path has as its goal the state of union with God. It starts by Quest. For each traveler the journey to this goal is unique; it is the journey "of the alone to the Alone." Yet there are also stages which all seekers pass through, trials, processes of purification and transformation. A seeker who passes through natural pleasures to unravels the truth, to move from plurality to unity. Quest is an inner will to move from self to Self. The state found in the heart of the wayfarer to seek knowledge and to study truth and hope. The second step is love. If the wayfarer to be in love, motivations and the demands will need to be recognized and released. There really is nothing to lose except the useless suffering produced by these demands. The most important factor in this step is pain. Attar considers love as divine gift and considers it is given to one who passes through and filled his heart with pain of love. Here the wayfarer forget self and seek himself in the mirror of Beloved. The next step is Valley of Knowledge, and it is the attribute of one who recognizes Beloved and his names. He is aware of all aspects and details of self and Self. After this recognition, now is the time of Detachment from all the longings. F. L. Lucas proposes purgation as the meaning of catharsis and describes, it is the human soul that is purged of its excessive passions[6].It is the needlessness or the attainment of the soul to a state without a worldly desire. Here, what is assumed to be reality vanishes in favor of Unity. When the wayfarer understood there is no difference between self and the other selves, no distance between lover and beloved the being self will mean as same as being Self. The Knowledge of being unite cause Wonderment, where, rapt by the splendor of the Beloved, the Wayfarer becomes perplexed in wonder, finds that he or she has never known or understood anything. Astonishment is a matter of wisdom and wandering. But in mysticism, wonderment is a mediator that enters to the mystic's heart and leads him to the God. Because the essence of God does not apprehend by the narrow sense of reason and wisdom. God is the greatest secret that will not understand by knowledge and will always remain in awe and wonder. After the diminishing of wisdom is time to act, is time of unity between self and Self. In sufism it is called Fana means passing away or annihilation (of the self)which has three basic stages :

1-Fana fi Shaikh where the seeker annihilates in the being of his Murshid. 2- Fana fi Rasool where the seeker annihilates in the being of Rasool. 3-Fana Fillah where the seeker annihilates in the essence of Allah attained only through Ishq-eHaqeeqi.[7].what Attear means by Fana is none of them, he does not speak of denying self and obliteration but he means melting in the greater Self by poverty and annihilation.

Instead of seeking to maximize comfort and pleasure, the wayfarer training the Nafs to accept hardship and difficulty without objection. Anything that engenders self-importance, any kind of self-promotion, is differing from the immature values of the wayfarer. His self-effacement is a freedom from ego-based needs, not a form of low self-esteem.

This conflation of the self with the Self is evidence that most of us live in a state of self-deception and confusion about our being. In this confusion, routinely philosophy and dialog of the self, we construct and sustain is an illusion that serves as an obstacle between our existing awareness and the wider range 
of truths about our existence. According to Attar this barrier exists out of simple ignorance. Birds understand the purpose of Self is like the sun that can be seen reflected in a mirror. Yet, whoever looks into that mirror will also behold his or her own image.

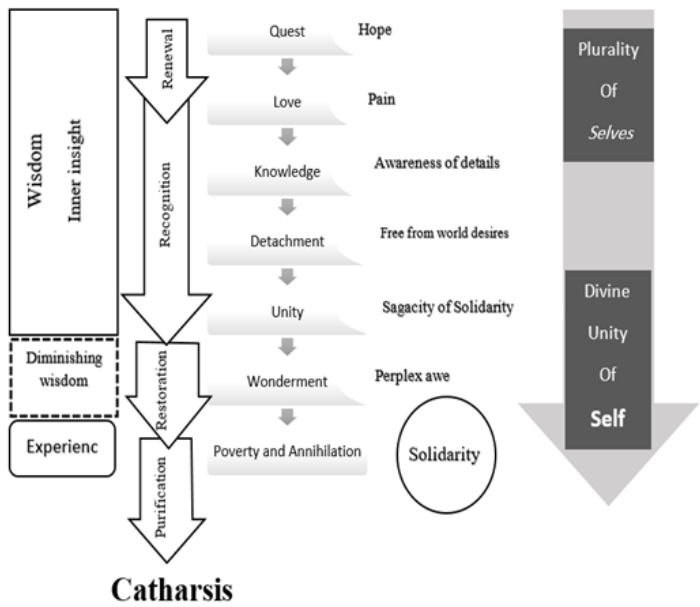

Fig. 1: Intuitive Development at the Conference of Birds

\section{BIODANZA}

Biodanza is a group dance therapy literally means the Dance of life. While traditional psychotherapy is interested in analyzing the wounded part of the individual, Biodanza focuses on the community expressing higher qualities of the human inner self and healthy states of awareness. The creator of Biodanza is Rolando Toro. During WWII he deeply suffered from the horrors and human misery to death and demolition. He developed Biodanza as a remedial to revert human sorrow and retrain him about relationships, love and sympathy. According to "R. Toro", Biodanza is intended to encourage psycho-physiologic self-organisation (selfregulation). The experiences in the context of this intervention aim to mobilise "powers of self-healing" and thereby increase feelings of self-confidence and joy[8]. Biodanza does not focus so much on the complications but on a person's existing resources. It works towards helping reach to capacities. The Method he called Biodanza is organized into five categories:

Vitality - health, vital impetus, happiness to be alive

Sexuality - sexual pleasure, eroticism, reproduction, passion

Creativity - innovation, construction, imagination, openness

Affection - love, friendship, altruism, empathy

Transcendence - connection to nature, feeling part of a greater totality.

Toro considers that when these five classes are developed within a person, they can experience inner stability and psychological health. The movements bring intuitive emotional response with the help of music match to the movements:

For the category of Vitality the music would be euphoric, happy, energizing;

2. For the category of Sexuality the music would be erotic, flowing, sensual;
3. For the category of Creativity the music would be expressive, different, intense,

inspirational;

4. For the category of Affection the music would be tender, soft, flowing, harmonious;

5. For the category of Transcendence the music would be sublime, ethereal, mysterious, glorious[9].

The different dances within the Biodanza sessions were designed to pass through the states of identity (sympathetic) and regression (parasympathetic)

In the table that follows descriptions of the 5 lines of experiences (vivencias) and the associated experiences, emotions and feelings are presented[10].

TABLE I: DESCRIPTION OF THE 5 LINES OF EXPERIENCE AND THE ASSOCIATED EXPERIENCES, EMOTIONS AND FEELINGS OR THE “EVOLUTIONARY” EXPERIENCES[10].

\begin{tabular}{|c|c|c|c|}
\hline $\begin{array}{l}\text { Protovivencia } \\
\text { (Protovivencias } \\
\text { are the primal } \\
\text { experiences of } \\
\text { early } \\
\text { childhood) }\end{array}$ & $\begin{array}{l}\text { Line of } \\
\text { Experience; } \\
\text { Vivencia }\end{array}$ & $\begin{array}{l}\text { Emotion, } \\
\text { Feeling }\end{array}$ & $\begin{array}{l}\text { Adaptive } \\
\text { Experience }\end{array}$ \\
\hline $\begin{array}{l}\text { movement, vital } \\
\text { energy }\end{array}$ & vitality & $\begin{array}{l}\text { joy, life } \\
\text { impulse, } \\
\text { enthusiasm }\end{array}$ & autonomy \\
\hline $\begin{array}{l}\text { contact, } \\
\text { affection }\end{array}$ & sexuality & $\begin{array}{l}\text { desires, } \\
\text { pleasure }\end{array}$ & $\begin{array}{l}\text { orgasmic } \\
\text { connection, } \\
\text { lust, } \\
\text { sensuality }\end{array}$ \\
\hline $\begin{array}{l}\text { freedom, } \\
\text { expression, } \\
\text { curiosity }\end{array}$ & creativity & $\begin{array}{l}\text { creative } \\
\text { enthusiasm }\end{array}$ & $\begin{array}{l}\text { artistic } \\
\text { creation, } \\
\text { scientific } \\
\text { creation } \\
\end{array}$ \\
\hline $\begin{array}{l}\text { protection } \\
\text { (security) eating } \\
\text { (food) }\end{array}$ & emotionality & $\begin{array}{l}\text { affection, } \\
\text { love, } \\
\text { friendship, }\end{array}$ & altruism \\
\hline $\begin{array}{l}\text { harmony } \\
\text { (harmonic } \\
\text { relationship } \\
\text { with } \\
\text { environment), } \\
\text { free breathing }\end{array}$ & transcendence & $\begin{array}{l}\text { happiness, } \\
\text { serenity, } \\
\text { calmness }\end{array}$ & ecstasy \\
\hline
\end{tabular}

\section{THE Mystery Of The SelF In BiodanZA}

When we contemplate carefully on self, it becomes clear that deficiency awareness of it. The many autonomous functions of our organs are themselves sign that there are processes within the self of which we are seldom if ever aware. Indication that is even more powerful is the mental dimension, where awareness, the storage of memories, and the mystifying content of our dreams reveal the existence of unconscious mind. So we cannot think, speak the self with complete knowledge and understanding. We are often unaware of the mystery of the self, Biodanza helps to understand. At first ,There is positive relationship between emotional intelligence and mental vitality with self-efficacy[11]. Vivenciai is in this purpose and means an intense perception of being alive in the here-and-now that produces emotional, somatic, and visceral effects; it is the intuition of life's immediacy. In Biodanza sessions, through providing rich environment by using "positive ecofactors" such as appropriate music, moving, 
group-encounters, as well as touching (including caressing), participants are invited spontaneously to immerse themselves directly and wholly in the here and now experiences (vivencias)[12]. So the first step is to receive self as a part of surroundings, it meant advance a new self-concept according to moment environment. Sometimes it seems around us is filled with qualms, as if we are overhanged in darkness, where any movement at all might send us falling to our doom. This darkness is Ecofactor that harm precious illusions of self .Ecofactors" themselves in Biodanza are defined as environmental factors stimulate or inhibit the unfolding of human potential [12]. Entering into the mystery of the self is therefore essential to liberation from some of the human fallaciousness and restrictions. Meta-analysis examined the relationship between self-efficacy and performance in a sport [13] and then any movements like dance. Person with poor physical health usually has poor emotional condition and low self-esteem. The next step after focusing on biological harmony is sexuality awareness. Both parenting, social rules, religion and sexual orientation play a role in the formation of intense and tension. Sensuality includes stimulating movements and sensations for asphyxiating sexual repression, thereby allowing access to the sources of aspiration and gender identity. Sensuality pertains to the erotic desire, reproductive capacity and the ability to feel pleasure .It is the path of freedom in realizing and actualizing more of our profound potentials, for out of this mystery emerges the amazing light of creativity that dancers express in Biodanza. Creativity indicates expressive and innovative impulses, existential and artistic resourcefulness, and the power to invent dances .There is the correlation between the creativity with physical self, social self, temperament self, educational self, moral self intellectual self and total self-concept[14]. Interpersonal relationships also improve as long as dancing in group. Creativity refer to to the renewal that must be applied to one's individual life to reconstruct, put creativity in each act and to involve in creative activities. Creativity is a mental ability like intelligence and not significant relationship with the selfconcept. What Boidanza means by creativity is that the dancer can find a better way to express him /herself. When you express yourself by the words of body movement which is universal language it can improve your communication with the others who has not any concept of you and your world. As individuals, we are all aware of the powers around an within us which in various degrees affected by them . however ,many of us fail to consider their origin. Basically mobilization of power rests with man and his creativity. Man achieves using his individual creative power as a result of using his individual strengths. These strengths are power- the individual's power to perform, to act in various ways such as physically, emotionally, intellectually and creativity. The use of man's inner strengths and his perception of these strengths aid in the further development of his feeling about himself or what can be called self-concept . if one values himself, believes himself to be capable and generally expects to succeed in what he attempts, he is more free to venture into the unknown ,challenging himself with new goals[15]

Now is time to the act of Affectivity and passion with others that involves ceremonies of convergence, relationship rituals, and dances of solidarity, as they provide affective re-education and thereby access to friendship and love .Affectivity pertains to altruistic love for human beings and for life in general. It is the affective womb that everybody can manifest to contain others [12]."Rogers" (1961)states that the healthy personality is one's capable of admitting any and all experiences and integrating these experiences, allow it entrance to his consideration and relate it in some fashion to the existing ideas he holds of himself and the word[16].

At this time is the transcendence turn, which suggests dances in nature and in water: dances of the four elements (water, air, earth, and fire) as they connect participants with the notion of universal harmony, awakening ecological awareness and access to Toro's concept of cosmic consciousness.

Regression is the reduction or revocation of willful, cortical activity. This state has a healing, regenerative effect on the organism by stimulating homeostasis. In Biodanza, the regressive state is an experience of harmony of the primal life functions, such as the instincts. In the state of regression, we are in touch with our healthy essence, which is distinctly separate from cultural and repressive values. In this state, we strengthen the balance and stability of the living system [10]. Biodanza is a horizontal continuum that starts by expressing self-individual and ends to human integration as capital Self.

This self-regulation refers to the natural alternation between the various states of mindfulness, consciousness, organic renewal and leads to the integration process. Catharsis in this spiritual-body regulation happens in the sense of ecstasy. The intuitive development in Biodanza is illustrated below: 


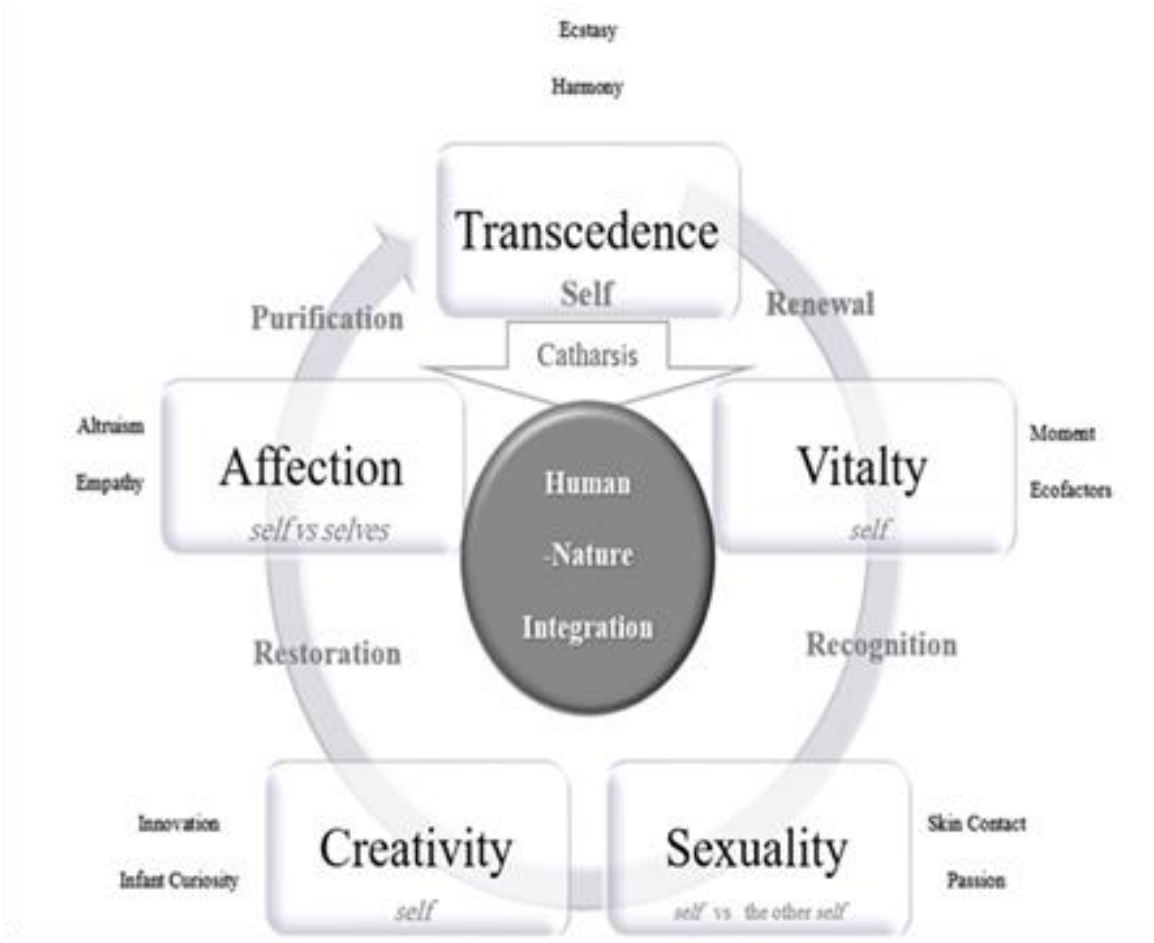

Fig. 2: Body and spiritual awareness in Biodanza

\section{CONCLUSION}

The term Catharsis is originally used in Aristotle's Poetics in its literal medical sense. It has been used in phycology by Sigmund Freud and Josef Breuer and adopted by modern psychotherapy, mostly by Freudian psychoanalysis, to define the act of expressing, or more accurately, experiencing the deep emotions often associated with events in the individual which had been repressed or ignored, and had never been adequately experienced.

The Conference of birds, the poem by attar has been analyzed from Aristotle's aspect. To free from belongings, to release from the self, seven valleys is suggested by Attar to be passed to reach the Simorgh as the Self. The mystic journey of Birds is a hierarchical passage. Mysticism can be defined as an experience where one personally knows, through straight awareness, the source of all being. Many call this source God; the Divine or the Cosmic. The point is, the experience is noetic. The art of mysticism can be learned and attar tries to teach it by his symbolic poem which starts by inner insight of Quest and followed by the six more valleys end to Integration. Desirelessness is the one of these steps to of consciousness. This concept can be easily misinterpreted by the western mind as having no ambition, objectives, or trend in life. More spiritually interpreted, this means a change in consciousness, which transcends yearning for that which one does not have, to accepting that which is already given. Mysticism in conference of birds is not just a belief. It is simply an art of movement from plurality to Unity. The mystical experience transcends selves. Often the wayfarer will receive a feeling that far surpasses anything which could be conveyed by words. Furthermore, this insight, devoid of ego, is thoroughly comprehended as truthful. Mind-Shifts Encountered on the Mystic Path. The merge of self with the Self is the result of the matrix of transformation, refining, purifying. this stage of evolution is often referred to as death and dying process but Simorgh is a bird that never dies so this conflation means immortality , join to the grater Self not just denying self. All personal will is surrendered to Divine Will. That identification makes its own effects; rehearsal, recognition, transformation and healing through grace. This is usually not an easy concept for the beginning mystical mind to reach, consequently, create a struggle in consciousness.

Three conceptions of catharsis are distinguished - the Dramatic model, the Clinical model and the Experimental model. The Dramatic and Clinical models are seen to focus on affective engagement and change. They are more similar to style of Biodanza while differing in the vicarious nature of the cathartic experience, in the degree of cognitive representation entailed, and in the nature of the interpersonal context. The Experimental model is seen to be addressed to the more general problem of aggression reduction through aggressive acts [16] ,but Biodanza is to reduce stress trough poetry of human encounter.

This group dance, not just offering usual benefits of dancing as a physical movement; it activates affective potentials to communicate and connect with ourselves as well as with other othee selves and the nature as the Divine Self. The Dramatic and Clinical models of catharsis are viewed as more specific and germane. This cathartic release of emotions by Biodanza is often believed to be therapeutic for affected individuals. 
Many therapeutic mechanisms have been seen to aid in emotional recovery. There has been much debate about the use of catharsis in the reduction of Stress. Special situations like dancing in-group can provoke physiological, behavioral, cognitive, expressive, and subjective changes in individuals that ends to catharsis. Biodanza also can leads to collective catharsis . Collective emotional events share similar responses. When communities are affected by an emotional event,like the moment in biodanza, members repetitively share emotional experiences. Catharsis presses a series of trigger points that releases the vented up emotions in the human body, unconscious mind and subconscious mind. These emotions manifest in forms of body expression. Biodanza is based on Catharsis - a specific personal repercussions from the journey of mind and body. The way to aliveness, passion, innovation, empathy and then join to the nature. Ingrained patterns in the body and mind that keep one imprisoned in the body, and to experience the freedom and peace that are hidden in nature behind these prison walls. . These include recognition of the internal and external expressive forms that gave rise to personal catharsis, and the rediscovery of individual creative voice of identity. In the process of deconstructing the movement process, certain issues are identified such as behavior, identity, narrative and the construction of the other or the external expressive form, which are integral aspects in identifying personal catharsis. This enables the relevance of catharsis as a stress management technique of self in connection with other selves and the transcendence of nature as Self. The mystic, the dancer, now being born in the organic renewal, begins to grasp the idea of transformation ,purgation, cleansing through grace which is experienced by identifying with the nature of being as part of greater harmony. Identifying with old thought embryonic patterns keeps one in a prolonged cycle of harmony with environment and must give way now to innovate new way of expression. Biodanza dancer's mind identifies with Integration only. That identification produces its own effects; renewal, recognition, transformation, and healing through grace.

\section{ACKNOWLEDGMENT}

S. M. (Author) thanks Dr. M.Yousefian who taught her to look profoundly in every performative phenomenon.

\section{REFERENCES}

[1] F. Ațtār, The Conference of the Birds, translated by Sholeh Wolpé, New York City: W. W. Norton \& Co., 2017.

[2] F.'Ațāar, The Conference of the Birds, translated by Afkham Darbandi and Dick Davis, Penguin Classics., 1984, re-edited as The Canticle of the Birds, Diane de Sellier Éditeur, 2013.

[3] H.Razmjoo, The Ideal and Perfect Man in the Persian Epic and Mystical literature, Tehran: Amirkabir.1996. 432p.

[4] A.Kasiri.(2016). Epic and mystic hero in Persian culture-a comparative study on the characters of hero in Shahnameh of Firdausi besides Persian miniatures. IIOABJornal.[online] . Vol. 7. Suppl 4.pp 463-473. Available

https://www.iioab.org/articles/IIOABJ_7.S4_463-473.pdf

[5] A,Berndtson, . Art, Expression, and Beauty, $1^{\text {st }} \mathrm{ed}$, Holt, Rinehart and Winston, 1975, p. 235.
[6] F.L.Lucas, F. L, Tragedy in Relation to Aristotle's Poetics ,Hogarth Press,

1927, p. 24.

[7] H.Sakhi Sultan, M.Najib-ur-Rehman, Sultan-Bahoo-The-Life-andTeaching, Pakistan: Sultan-ul-Faqr Publications (Regd) ,2014,p. 288.

[8] Toro, R. "The Theory of Biodanza",1995, p60.[online] .Available www.biodanzaschule-leipzig.de

[9] S.Bello,"Biodanza and Affectionate Intelligence "presented at the American Group Psychological Association, 2003 PhD.p2.

[10] M.Stück,A.Villegas,K.Bauer,R.Terren,V.Toro and U.Sack," Psychoimmunological process evaluation of Biodanza,"on Journal of Pedagogy and Psychology SignumTemporis.voulum2,number1 p102. september2009.

https://doi.org/10.2478/v10195-011-0024-7

M.Ghanbaritalab, R.Sheikholeslami," The relationship between emotional intelligence and mental vitality with self-efficacy," frooyesh Psychological Journal, vol.4 (3), pp 75-86, 2015.

[11] T.Kubo," Biodanza through the Lens of the Integral Theory:Towards Body-mind Integration",mongraph. San Francisco School of Biodanza May 2012.

[12] S,Moritz, D.Feltz, K. Fahrbach and D, Mack (Sep2000) The relation of self-efficacy measures to sport performance: a meta-analytic $\begin{array}{llll}\text { review.pubmed } & \text {.[online]. } & \text { 71(3).pp280-94. Available: }\end{array}$ https://www.ncbi.nlm.nih.gov/pubmed/10999265 https://doi.org/10.1080/02701367.2000.10608908

[13] L. Majed Al-Qaisy ,J.Turki. (2011).Adolescents Creativity, SelfConcept and Achievement Motivation, British Journal of Arts and Social Sciences [online].2(2).pp88-101. Available: http://www.bjournal.co.uk/BJASS.aspx

[14] D.Sisk.(1972).Relationship Between Self Concept and Creativity: Theory Into Practice. Gifted Child Quarterly-SAGE Journals [online].16(3).p229. https://doi.org/10.1177/001698627201600305

[15] C.Rogers, On Becoming a Person, Boston: Houghton Mifflin Company, 1961.

[16] S.Feshbach, (1984). The catharsis hypothesis, aggressive drive, and the reduction of aggression .Aggressive Bbehavior.10(2).pp91101Available: https://onlinelibrary.wiley.com/doi/abs/10.1002/10982337

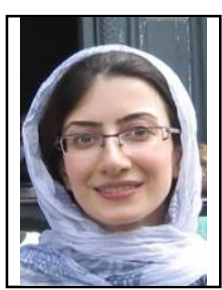

Simin Meshkati
Iran,Tehran
1981/09/09
M.A dramatic literature-Tarbiat Modares University-
Tehran,Iran 2013 communication(Journalism)-IRIB
M.A
University,Tehran,Iran 2011
B.A news translation-School of Media Studies-
Tehran,Iran 2009

B.S biochemistry-Islamic Azad University-Falavarjan, Iran 2003

/sImIn/

- Meshkati, S., \& Yousefian, MJ. (2016) a Comparison Study on Dramatic Aspects of Iranian Identity in Three Decades of Iranian Drama. Theater quarterly, 65 (-). Pp66-88.

- Yousefian, MJ. \& Meshkati, S. (2015). Functions of Masks and Androgyny Intrigue in Characterizing of Contemporary Iranian Drama. Journal of dramatic arts and music,

- 6(11). Pp5-21.

- Meshkati S., \& Minavand, M. (24-28Jul. 2012). The Study of CounterHegemony in Press TV News Broadcasting. International congress of Humanities and Social Sciences Research-Paris, France, Pp179-191.

- Yousefian, MJ. Meshkati S., \& Mokhtabad, M (Sep. 2012). The Comparative Study on the Effects of Islamic Identity on 3 last decades Plays of Iran (1980-2010). The world conference on Islamic thought: contemporary challenges and realities Ipoh, Perak: Malaysia. Pp 1300-1312.

Current and previous research interests :Drama, Dance, performance Ms. Simin Meshkati

- Outstanding student among entrances of academic year (2010-11) : Ranked first in Dramatic Literature 
15th LISBON-PORTUGAL International Conference on Literature, Languages, Humanities and Social Sciences (L2HSS-19) June 19-21, 2019 Lisbon (Portugal)

- Outstanding student among entrances of the academic year (2006-7):

Ranked First in Communication-Journalism (M.A) at the IRIB University. 